\title{
Article
}

http://dx.doi.org/10.11646/phytotaxa.167.3.9

\section{Confirmation of Valeriana nivalis (Valerianaceae) to the Argentinian flora}

\author{
CHRISTIAN A. ZANOTTI*, MABEL A. SUESCÚN \& JUAN M. ACOSTA \\ Instituto de Botánica Darwinion, IBODA-CONICET, Casilla de Correo 22, B1642HYD San Isidro, Buenos Aires, Argentina. \\ *author for correspondance czanotti@darwin.edu.ar
}

\begin{abstract}
We confirm the occurrence of Valeriana nivalis to the Argentinean flora, based on results of both morphological and molecular phylogenetic studies. We also include a taxonomic description, distribution, and additional information to discern V. nivalis from $V$. pycnantha.
\end{abstract}

Key words: Argentina, Flora, New record, Taxonomy, Valeriana

\section{Introduction}

Valeriana Linnaeus (1753: 31) includes ca. 250 species distributed all over the world except Australia and New Zealand. Most Valeriana species grow in temperate regions of the northern hemisphere, and particularly along the South American Andes, which is an important center of secondary diversification (Kutschker 2008a, 2011). The Argentinean flora includes 48 species of Valeriana, mainly distributed along the Andes and central mountains (Xifreda 1999, Kutschker 2008b, 2011).

Diagnostic characters used to discriminate species in most local taxonomic and floristic works on Valeriana (eg. Borsini 1942, 1944, 1966, 1999, Cabrera 1993) are considered inadequate (Reese-Krug \& Weberling 1991). In addition, some nomenclatural problems have come to light (Reese-Krug \& Weberling 1991, 1996). Valeriana nivalis Wedd. was recorded for Argentina by Borsini (1942, 1944, 1966, 1999) and Cabrera (1993). However, those records were based on specimens of Valeriana pycnantha A. Gray (Reese-Krug \& Weberling 1991) and so V. nivalis did not occur in later accounts (Xifreda 1999; Kutschker 2008a).

After examining new collections from Jujuy province, Argentina (specimens from BAA, CONC, F, LIL, SI, ULM) and original descriptions, we confirm the existence of $V$. nivalis to the Argentinean flora. This taxonomic placement was confirmed using molecular phylogenetic analysis, based on Bell et al. (2012). Morphological description, distribution and additional material examined of $V$. pycnantha are also included to update information of a sympatric species that could be easy confused with it. In addition, we include $V$. altoandina Cabrera as a new synonym of $V$. nivalis based on a morphological analysis.

\section{Materials and methods}

We examined collections from BAA, CONC, F, LIL, SI, ULM, original descriptions, floras (Borsini 1942, 1944, 1966, 1999, Cabrera 1993) and taxonomics works (Reese-Krug \& Weberling 1991).

We amplified and sequenced the chloroplast marker trnL-F and the ribosomal ITS region of $V$. nivalis and $V$. pycnantha. DNA extraction, sequencing and aligment were carried out as described in Bell et al. (2012). We used Maximum Likelihood (ML) analysis to infer phylogeny as performed in Bell et al. (2012). Specimens used in molecular analysis are marked with (*) in the list of examined material of each species. Taxon names and GenBank accession numbers for ITS and $t r n L-F$ sequences used in the phylogenetic analysis are given in TABLE 1. 


\section{Acknowledgements}

To Raúl Pozner, for critical reading and assistance with English translation. To Fernando Biganzoli (BAA), Alicia Marticorena (CONC) and Gerhard Gottsberger (ULM) for the images of the herbarium vouchers. To Adriana Kutscher $\&$ Charles Bell for the molecular data supplying. To the curators of the herbaria cited in this work.

\section{References}

Bell, C.D., Kutschker, A. \& Arroyo, M.T.K. (2012) Phylogeny and diversification of Valerianaceae (Dipsacales) in the southern Andes. Molecular phylogenetics and evolution 63: $724-737$.

http://dx.doi.org/10.1016/j.ympev.2012.02.015

Borsini, O.E. (1942) Valerianáceas de Tucumán. Lilloa 8: 353 -377.

Borsini, O.E. (1944) Valerianaceae. In: A. H. Descole (ed.). Genera et Species Plantarum Argentinarum II. Fundación Miguel Lillo, Talleres gráficos de G. Kraft Ltda. S.A., Tucumán: 275 -372.

Borsini, O.E. (1966) Valerianáceas de Chile. Lilloa 32: 375- 476.

Borsini, O.E. (1999) Valerianaceae. In: M. N. Correa (ed.), Flora Patagónica. Colección Científica del Instituto Nacional de Tecnología Agropecuaria 8(6): 448-468.

Cabrera, A.L. (1993) Valerianaceae. In: A. L. Cabrera (ed.), Flora de la Provincia de Jujuy. Colección Cientifica del Instituto Nacional de Tecnología Agropecuaria 13(9): 443-469.

Gray, A. (1862) Valerianaceae. Proceedings of the American Academy of Arts and Sciences 5: 322.

Kutschker, A.M. (2008a) Valerianaceae. In: F. O. Zuloaga, O. Morrone \& M. J. Belgrano (eds.), Catálogo de las Plantas Vasculares del Cono Sur. Monographs in systematic Botany from the Missouri Botanical Garden 107(3): 3091 -3101.

Kutschker, A.M. (2008b) Morfología del fruto en especies de Valeriana (Valerianaceae) de los Andes australes. Darwiniana $46(1): 17$ -35 .

Kutschker, A.M. (2011) Revisión del género Valeriana (Valerianaceae) en Sudamérica austral. Gayana Botánica 68(2): 244 -296. http://dx.doi.org/10.4067/s0717-66432011000200016

Linnaeus, C. (1753) Species Plantarum, vol. 1. Laurentius Salvius, Stockholm, 560 pp.

Reese-Krug, H. \& Weberling, F.H.E. (1991) Zur taxonomie hochandiner Valeriana-Arten (Valerianaceae) I. Valeriana nivalis Wedd. und V. pycnantha A. Gray. Botanische Jahrbücher Systematik 112(3): 399 -410.

Reese-Krug, H. \& Weberling, F.H.E. (1996) Zur taxonomie hochandiner Valeriana - Arten (Valerianaceae). II. Valeriana globularis A.Gray, V. condamoana Graebn, und V. petersenii sp. nov. Botanische Jahrbücher Systematik 118 (2): 159 -175.

Weddell, H.A. (1858) Chloris andina II. P. Bertrand, Paris. 316 pp.

Xifreda, C.C. (1999) Valerianaceae. In: F. O. Zuloaga \& O. Morrone (eds.), Catálogo de las Plantas Vasculares de la República Argentina II. Monographs in Systematic Botany from the Missouri Botanical Garden 74: 1131 -1136. 